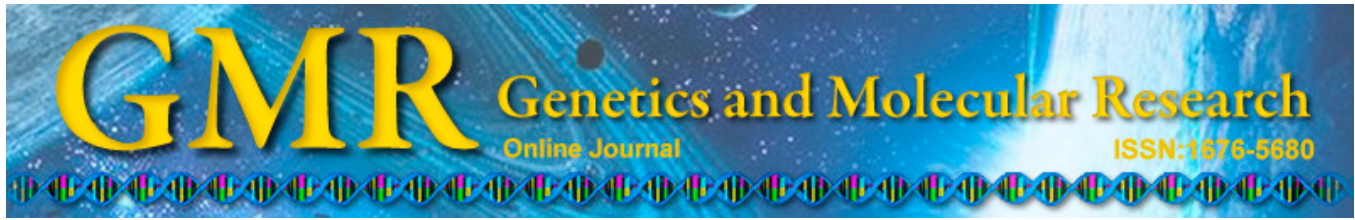

\title{
Expression and function of PDGF- $\alpha$ in columnar epithelial cells of age-related cataracts patients
}

\author{
J. Wei ${ }^{1}$, H. Tang ${ }^{1}$, Z.Q. Xu ${ }^{2}$, B. Li ${ }^{3}$, L.Q. Xie ${ }^{1}$ and G.X. Xu ${ }^{1}$ \\ ${ }^{1}$ Department of Ophthalmology, The Second Hospital of Suzhou University, \\ Jiangsu, China \\ ${ }^{2}$ Department of Ophthalmology, The Sixth People's Hospital, \\ Shanghai Jiaotong University, Shanghai, China \\ ${ }^{3}$ Department of Ophthalmology, \\ Shanghai Tenth People's Hospital Affiliated Tongji University, Shanghai, China \\ Corresponding author: G.X. Xu \\ E-mail: XuGuoxu9892@163.com
}

Genet. Mol. Res. 14 (4): 13320-13327 (2015)

Received April 16, 2015

Accepted July 20, 2015

Published October 26, 2015

DOI http://dx.doi.org/10.4238/2015.October.26.28

\begin{abstract}
We studied the expression and function of plateletderived growth factor A (PDGF- $\alpha$ ) in the lens epithelial cells of cataracts patients. Ninety age-related cataracts patients were recruited in our hospital between January 2012 and January 2014. The expression levels of platelet-derived growth factor receptor (PDGFR) in the anterior capsule of the lens at different degrees of turbidity, and PDGF- $\alpha$ in the aqueous humor were detected. A human lens epithelium cell line was also cultured and studied. To investigate its function, PDGF- $\alpha$ was used to treat a PDGFR-silenced human lens epithelium cell line to observe changes in the proliferation, transfer, and epithelial mesenchymal transition (EMT). The expression of PDGF- $\alpha$ and its receptor increased in patients with more serious cataracts. Lens epithelium cells stimulated by PDGF- $\alpha$ showed greater proliferation and migration. The degree of EMT was also upregulated in cells stimulated by PDGF- $\alpha$.
\end{abstract}


However, silencing the expression of PDGFR inhibited the effects. The development and severity of age-related cataracts was related to the secretion and expression of PDGF- $\alpha$. This may be a new therapeutic target for cataracts treatment.

Key words: Lens epithelium cells; Platelet-derived growth factor A; Cataracts

\section{INTRODUCTION}

More than $50 \%$ of blindness is caused by cataracts globally, and age-related cataract development is particularly common (Lundström et al., 2013). However, the pathogenesis of cataracts is still unclear. Following the continuous development of molecular biology techniques, cytokine secretion and protein expression detection in the pathological location have been widely used in various diseases (Behndig et al., 2012). Previous studies have confirmed that plateletderived growth factor $\mathrm{A}(\mathrm{PDGF}-\alpha$ ), an active peptide that strongly promotes cell proliferation, is correlated with the development of a variety of eye diseases such as retinal pigmentation (Arshinoff and Bastianelli, 2011). Here, we attempted to assess the expression of PDGF- $\alpha$ in lens cells, and investigated its relationship to cataracts and their development mechanism.

\section{MATERIAL AND METHODS}

\section{Clinical specimens collection}

Ninety age-related cataracts patients were recruited in our hospital between January 2012 and January 2014. Thirty-two cases were male and 58 were female, and patients were aged 45-76 years. All patients were treated by phacoemulsification. Other eye diseases or major systemic diseases were ruled out before surgery. Based on slit-lamp examination after pupil enlargement, the patients were classified according to the lens opacities classification system LOCS II. Group 1 refers to mild, group 2 to medium, and group 3 to severe opacity. Each group contained 30 patients. Continuous circular capsulorhexis was used in the operation to take off the capsule membrane in the central scope before the lens. Part of the capsule was preserved immediately at $-80^{\circ} \mathrm{C}$, while the remaining part was fixed with $4 \%$ paraformaldehyde and embedded in paraffin for storage at $-20^{\circ} \mathrm{C}$. Aqueous humor $(100 \mathrm{~mL})$ was extracted from the patients during the operation and centrifuged. The supernatant was stored at $-80^{\circ} \mathrm{C}$. The protocol of this study was approved by the Second Hospital of Suzhou University (Jiangsu, China). Informed consent was obtained from all subjects.

\section{Clinical index detection}

Sections (4- $\mu \mathrm{m}$ thick) from paraffin blocks were cut and placed in a $60^{\circ} \mathrm{C}$ APES bath for $24 \mathrm{~h}$. The slides were then incubated in xylene for dewaxing. The baths were changed, and the procedure was repeated twice. After the antigen had been repaired with citric acid buffer, the slides were treated with hydrogen peroxide solution and methanol to remove endogenous peroxidase. After blocking with goat serum, the slides were incubated overnight at $4^{\circ} \mathrm{C}$ in 1:100 platelet-derived growth factor receptor (PDGFR) antibodies (Boster, Wuhan, China). 
Then a biotin-labeled secondary antibody was used and colored by DAB substrates. Positive PDGFR in the specimens was evaluated as follows: five visual fields with 50 cells in each field were recorded for a positive cell number and positive strength. Positive grades were as follows: negative, 0 ; slight yellow coloration in the cytoplasm, 1; major claybank in the cytoplasm, 2; and large number of claybank granules in the cytoplasm, 3. The final grading was evaluated by positive cell number x positive strength. For the aqueous humor, an enzymelinked immunosorbent assay kit (Boster, Wuhan, China) was used to detect PDGF- $\alpha$ expression level according to the operation manual.

\section{Cell culture}

Human lens epithelial cell line SRA01/04 was maintained in minimum essential medium (MEM) with 20\% fetal calf serum (Gibco, Grand Island, NY, USA) in a humid atmosphere containing $5 \% \mathrm{CO}_{2}$ at $37^{\circ} \mathrm{C}$. Cells in the logarithmic phase of growth after 2-3 passages were used for all experiments.

\section{Cell stimulation and detection}

PDGFR- $\alpha$ antisense oligonucleotide was transfected to construct PDGFR inactivation cells. Specifically, SRA01/04 cells were cultured in serum-free MEM 1 day before transfection. PDGFR- $\alpha$ antisense oligodeoxynucleotide (Shenggong, Shanghai, China) was added to the medium and incubated for $8 \mathrm{~h}$, and then the cells were cultured for $24 \mathrm{~h}$ to complete the transfection.

\section{Cell migration test}

A $50 \mathrm{mg} / \mathrm{L}$ Matrigel-coated Transwell chamber (BD, USA) was used to test cell invasion capability. Cells $\left(2 \times 10^{5} / \mathrm{mL}\right)$ were seeded in the upper chamber with serum-free MEM and $600 \mu \mathrm{L}$ MEM with $20 \%$ fetal calf serum was put in the lower chamber. The normal or transfected cells were stimulated with or without $10 \mathrm{ng} / \mathrm{mL}$ PDGF- $\alpha$. After $36 \mathrm{~h}$ incubation, the penetrated cells were fixed and counted.

\section{Cell proliferation test}

Cells $\left(3 \times 10^{5} / \mathrm{mL}\right)$ were seeded in the dish. After $48 \mathrm{~h}$, cells were incubated in serumfree medium with $0.2 \%$ bovine serum albumin. The normal or transfected cells were stimulated with or without $10 \mathrm{ng} / \mathrm{mL}$ PDGF- $\alpha$. A sterile tip was used to make a 1-mm-wide scratch. The scratch was measured after 24,48 , and $72 \mathrm{~h}$ incubation.

\section{Epithelial mesenchymal transition (EMT) detection}

E-cadherin RNA and protein expression levels were detected in normal or transfected cells with or without $10 \mathrm{ng} / \mathrm{mL}$ PDGF- $\alpha$ stimulation for $24 \mathrm{~h}$ using real-time polymerase chain reaction and western blot, respectively. The primer used was:

E-cadherin forward: 5' GTACTTGTAATGACACATCTC 3'

Reverse: 5' TGCCAGTTTCTGCATCTTGC 3' 


\section{Statistical analysis}

Numerical data are reported as means \pm standard deviation and analyzed by the Student $t$-test or one-way analysis of variance. All statistical analyses were performed using the SPSS 17.0 software (Chicago, IL, USA). P values $<0.05$ were considered to be statistically significant.

\section{RESULTS}

\section{Clinical specimen detection}

The capsule was graded by immunohistochemical staining. The PDGFR grading gradually increased following increases in lens opacity. The score in group 3 was significantly higher than that in group 1 (Table 1).

Table 1. Clinical specimen detection.
\begin{tabular}{lccc} 
& & & \\
\hline Category & Group 1 & Group 2 & Group 3 \\
\hline PDGF-A in aqueous humor $(\mathrm{pg} / \mathrm{mL})$ & $242.31 \pm 48.79$ & $278.56 \pm 5233$ & $332.46 \pm 39.29^{*}$ \\
Lens scoring & $298.16 \pm 54.21$ & $381.22 \pm 66.54$ & $416.78 \pm 68.56^{*}$ \\
E-cadherin & $0.35 \pm 0.12$ & $1.33 \pm 0.38$ & $2.12 \pm 0.62^{*}$ \\
\hline
\end{tabular}

$* \mathrm{P}<0.05$.

This indicated that PDGFR expression in the patients' lenses was upregulated with cataract progression. The enzyme-linked immunosorbent detection produced similar results in the aqueous humor: the PDGF- $\alpha$ concentration in group 3 was markedly higher than that in group 1.

\section{Cell detection}

After stimulation by PDGF- $\alpha$, the proliferation and migration capability of normal lens epithelial cells was promoted significantly. However, when the PDGF- $\alpha$-related receptor PDGFR- $\alpha$ was blocked, the effect was reduced (Figure 1 and Table 2).

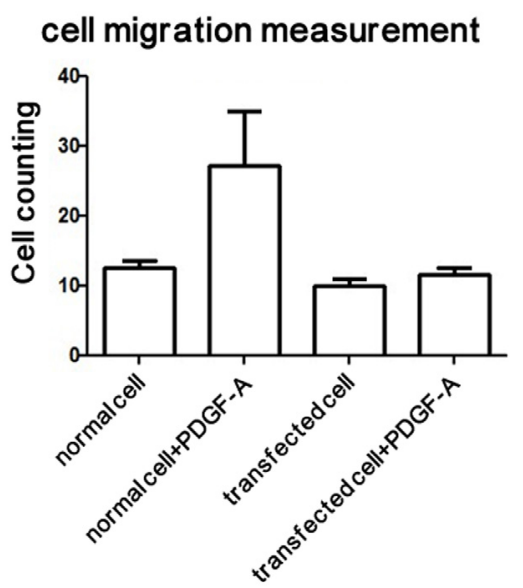

Figure 1. Transwell test. Cell-counting results of the four groups after transwell experiments. 
Table 2. Cell wound-healing recovery ratio (\%).

\begin{tabular}{lcccr}
\hline Time point $(\mathrm{h})$ & Normal cell & Normal cell + PDGF-A & Transfected cell & Transfected cell + PDGF-A \\
\hline 24 & $36.28 \pm 5.12$ & $52.35 \pm 6.98^{*}$ & $32.33 \pm 4.16$ & $30.18 \pm 3.21$ \\
48 & $68.66 \pm 5.12$ & $84.12 \pm 7.12^{*}$ & $59.79 \pm 5.22$ & $62.42 \pm 4.28$ \\
72 & $82.23 \pm 4.66$ & $96.79 \pm 2.18^{*}$ & $79.89 \pm 6.24$ & $83.56 \pm 3.98$ \\
\hline$* \mathrm{P}<0.05$ & & & &
\end{tabular}

To further evaluate the effect of PDGF- $\alpha$ on EMT, E-cadherin expression was measured with or without PDGF- $\alpha$ stimulation. The results showed that PDGF- $\alpha$ could increase E-cadherin expression in the cell line, while the EMT marker did not change when PDGFR was inhibited (Figure 2 and Figure 3). In clinical specimens, E-cadherin expression increased in line with the degree of lens opacity (Table 1 and Figure 3 ).

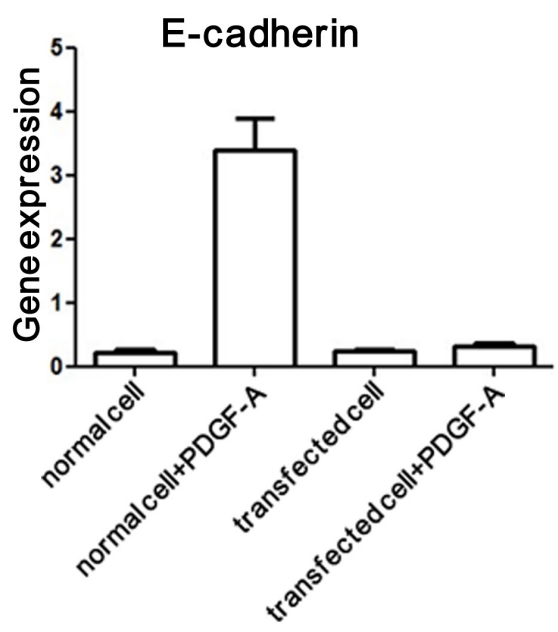

Figure 2. E-cadherin RNA expression. E-cadherin RNA expression in the four groups was detected by polymerase chain reaction.

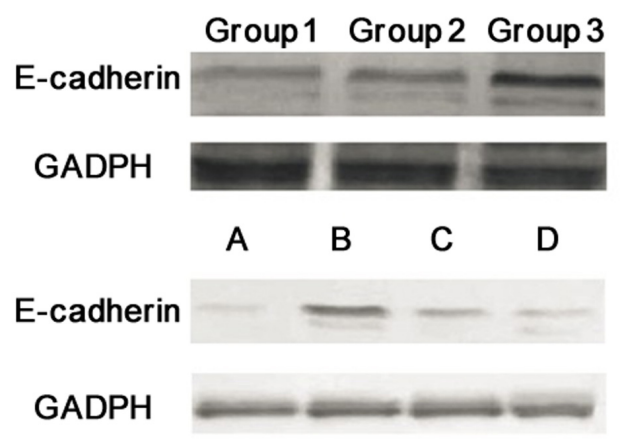

Figure 3. E-cadherin protein expression. E-cadherin protein expression was detected by western blot. Groups 1-3 represent lens specimens of increasing opacity. Groups A-D represent the four groups of cells with different treatments. $\mathrm{A}=$ normal cells + phosphate-buffered saline for $24 \mathrm{~h} ; \mathrm{B}=$ normal cells $+10 \mathrm{ng} / \mathrm{mL}$ platelet-derived growth factor A (PDGF-A) for $24 \mathrm{~h} ; \mathrm{C}=$ normal cells + phosphate-buffered saline for $24 \mathrm{~h}$; $\mathrm{D}=$ normal cells +10 ng/mL PDGF-A for $24 \mathrm{~h}$. 


\section{DISCUSSION}

The direct pathogenic characteristic of cataracts is opaque lenses, but its pathogenesis is complex, involving many influences such as heredity, metabolism, and environmental factors. It has been reported that ultraviolet radiation and glucocorticoids can cause cataracts. In recent years PDGF, an endogenous factor, has gradually aroused interest (Arshinoff and Bastianelli, 2011). PDGF is a cell factor that can promote mesenchymal proliferation and division, and is derived from mesenchymal tissue such as fibroblasts, epithelial cells, and endothelial cells. PDGF functions by combining with its cell surface receptor PDGFR (Arshinoff and Bastianelli, 2011; Mancino et al., 2011; Zhang et al., 2011). It has different subtypes such as A, $\mathrm{B}, \mathrm{C}, \mathrm{D}$, etc. Among those subtypes, PDGF- $\alpha$ is the most widely distributed and has the strongest biological effect because it can combine with the target cell PDGFR directly and induce downstream signaling pathways such as the PI3K/Akt, RAS-GAP, and ERK1/2 pathways, with corresponding biological effects (Behndig et al., 2011). Though the PDGF-PDGFR combination has a significant effect on regulating cell proliferation and division, this regulation is strictly controlled in normal tissue. Both the concentration of PDGF in local body fluids and PDGFR expression on local tissue cell surfaces are maintained at relatively low levels (Shukla et al., 2012). However, PDGF secretion and its stimulatory effects are activated during trauma, infection, or inflammation. Such stimulatory effects are of great significance for normal tissue repair, but excessive stimulus response tends to lead to adverse consequences such as fibrosis and abnormal cell distribution (Schultz et al., 2013).

PDGF exists in the aqueous humor and plays an important role in maintaining lens columnar epithelium proliferation and metabolism. When the columnar epithelium proliferates abnormally, the transparency of the lens is often affected. This may be an important pathogenesis of the cataract (Aldahmesh et al., 2012; Lundström et al., 2013; Schultz et al., 2013). We found that during the progression of the age-related disease, according to the opacity of the cataract, the positive rate of PDGFR in the anterior capsule group increased markedly. At the same time, PDGF- $\alpha$ protein concentration in the aqueous humor was also upregulated significantly. This result from the clinical specimens indicated that PDGF- $\alpha$ may be closely related to age-related cataracts progression. The PDGFR results also showed that the reactivity of the lens columnar epithelium to PDGF increased along with disease progression. Such a synchronous rise in the levels of the cytokine and the receptor, and the subsequent downstream stimulatory effects, will increase with cataracts progression.

The lens columnar epithelium is distributed under the anterior capsule and comprises simple cuboidal epithelial cells, which have the ability to proliferate and differentiate (Serrano-Aguilar et al., 2012). Such cells express PDGFR and can be stimulated by PDGF. Previous reports on cells have confirmed that PDGF can promote cell proliferation and transformation to mesenchymal cells (Yao et al., 2011). Our clinical results confirmed that PDGF- $\alpha$ was overexpressed in the higher lesion. To evaluate the pathogenic mechanism of such high expression, we completed the corresponding experiment in vitro.

First, after stimulation by PDGF- $\alpha$, it was observed that the repair and migration capability of epithelial cells in response to scratch was significantly enhanced. Previous research on the intracellular mechanism has shown that PDGF- $\alpha$ can activate the PI3K/Akt and ROSERK1/2 signaling pathways (Ursea et al., 2011; Groessl et al., 2013; Zeppieri et al., 2013). Friling et al. (2013) showed that activation of Akt and ERK1/2 has significant correlation with cell proliferation, and we observed a similar effect. Therefore, columnar epithelial cells in le- 
sions of the lens were stimulated by relatively high concentrations of PDGF- $\alpha$, while PDGFR expression was higher. All of the above cause stronger proliferation and migration capability.

Second, E-cadherin expression in the columnar epithelium increased significantly after PDGF- $\alpha$ stimulation. These results suggest that epithelial cells can be stimulated to transform into mesenchymal cells, and the cell morphology also becomes slender. Thus, PDGF- $\alpha$ can stimulate EMT in columnar epithelial cells. To further verify our discovery, clinical specimens were tested and similar results were observed. Thus, EMT also existed in the age-related cataracts patients.

Normal lens columnar epithelial cells have their own proliferation and differentiation laws. In elderly patients, however, such self-regulation slowly weakens and the characteristics of columnar epithelial cells are gradually lost (Kernt et al., 2012). However, PDGF- $\alpha$ concentration increases in the aqueous humor. PDGF- $\alpha$ can combine with and activate the PDGF- $\alpha$ receptor on the epithelial cells. It further promotes cell proliferation and migration activities. In the absence of trauma or external stimuli, such unregulated proliferation and migration has no benefit for the lens, whereas it may destroy the normal structure of the local columnar epithelium (Lovicu et al., 2014). Furthermore, the cells presented fibrosis characteristics after PDGF- $\alpha$ stimulus, which had various effects as the lens epithelial cells gradually decreased. The local columnar epithelium may eventually transform to fibrous tissue with no function, and lead to the formation of cataracts (Hiram-Bab et al., 2014; Raju et al., 2013). In the present study, we confirmed the presence of PDGF- $\alpha$ in the aqueous humor and its receptor activation from the clinical specimens, and further cell tests also verified that such an increase in PDGF- $\alpha$ could promote normal columnar epithelium fibrosis. Thus, PDGF- $\alpha$ may be an important factor for age-related cataracts progression. The promotion of EMT by PDGF- $\alpha$ was reduced by blocking its receptor and this is of positive significance for the treatment of cataracts.

In conclusion, PDGF expression in the lens columnar epithelium and PDGF- $\alpha$ concentration in the aqueous humor both increase significantly in age-related cataracts patients, and such increases coincide with an increase in lens opacity. Further in vitro experiments found that PDGF- $\alpha$ stimulation could improve the proliferation and migration of lens epithelial cells, and significantly promote EMT. PDGF receptor silencing in the epithelial cells can block this process. Considering that lens epithelial cell proliferation and EMT are both important pathogenic factors that can lead to opaque lenses, progression of age-related cataracts may be linked to PDGF- $\alpha$ overexpression and stimulation in the lens and aqueous humor. Moreover, PDGF could be a new therapeutic target for the treatment of age-related cataracts. Because there is still a lack of effective animal models to evaluate the role of PDGF- $\alpha$ blocking in the treatment of cataracts, further research is required.

\section{REFERENCES}

Aldahmesh MA, Khan AO, Mohamed JY, Alghamdi MH, et al. (2012). Identification of a truncation mutation of acylglycerol kinase (AGK) gene in a novel autosomal recessive cataract locus. Hum. Mutat. 33: 960-962.

Arshinoff SA and Bastianelli PA (2011). Incidence of postoperative endophthalmitis after immediate sequential bilateral cataract surgery. J. Cataract. Refract. Surg. 37: 2105-2114.

Behndig A, Montan P, Stenevi U, Kugelberg M, et al. (2011). One million cataract surgeries: Swedish National Cataract Register 1992-2009. J. Cataract. Refract. Surg. 37: 1539-1545.

Behndig A, Montan P, Stenevi U, Kugelberg M, et al. (2012). Aiming for emmetropia after cataract surgery: Swedish National Cataract Register study. J. Cataract. Refract. Surg. 38: 1181-1186.

Friling E, Lundström M, Stenevi U and Montan P, et al. (2013). Six-year incidence of endophthalmitis after cataract surgery: Swedish national study. J. Cataract. Refract. Surg. 39: 15-21. 
Groessl EJ, Liu L, Sklar M, Tally SR, et al. (2013). Measuring the impact of cataract surgery on generic and vision-specific quality of life. Qual. Life Res. 22: 1405-1414.

Hiram-Bab S, Katz LS, Shapira H, Sandbank J, et al. (2014). Platelet-derived growth factor BB mimics serum-induced dispersal of pancreatic epithelial cell clusters. J. Cell Physiol. 229: 743-751.

Kernt M, Thiele S, Neubauer AS, Koenig S, et al. (2012). Inhibitory activity of ranibizumab, sorafenib, and pazopanib on light-induced overexpression of platelet-derived growth factor and vascular endothelial growth factor A and the vascular endothelial growth factor A receptors 1 and 2 and neuropilin 1 and 2. Retina 32: 1652-1663.

Lovicu FJ, Iyengar L, Dawes LJ, et al. (2014). Lens Epithelial Cell Proliferation. In: Lens Epithelium and Posterior Capsular Opacificatio (Saika S, Werner L and Lovicu FJ, eds.). Springer, Japan, 59-80.

Lundström M, Barry P, Henry Y, Rosen P, et al. (2013). Visual outcome of cataract surgery; study from the European Registry of Quality Outcomes for Cataract and Refractive Surgery. J. Cataract. Refract. Surg. 39: 673-679.

Mancino R, Varesi C, Cerulli A, Aiello F, et al. (2011). Acute bilateral angle-closure glaucoma and choroidal effusion associated with acetazolamide administration after cataract surgery. J. Cataract. Refract. Surg. 37: 415-417.

Raju R, Jian B, Hooks JJ and Nagineni CN (2013). Transforming growth factor- $\beta$ regulates the expression of anosmin (KAL-1) in human retinal pigment epithelial cells. Cytokine 61: 724-727.

Schultz T, Conrad-Hengerer I, Hengerer FH and Dick HB (2013). Intraocular pressure variation during femtosecond laserassisted cataract surgery using a fluid-filled interface. J. Cataract. Refract. Surg. 39: 22-27.

Serrano-Aguilar P, Ramallo-Fariña Y, Cabrera-Hernández JM, Perez-Silguero D, et al. (2012). Immediately sequential versus delayed sequential bilateral cataract surgery: safety and effectiveness. J. Cataract. Refract. Surg. 38: 1734-1742.

Shukla AN, Daly MK and Legutko P (2012). Informed consent for cataract surgery: patient understanding of verbal, written, and videotaped information. J. Cataract. Refract. Surg. 38: 80-84.

Ursea R, Feng MT, Zhou M, Lien V, et al. (2011). Pain perception in sequential cataract surgery: comparison of first and second procedures. J. Cataract. Refract. Surg. 37: 1009-1014.

Yao K, Wang W, Zhu Y, Jin C, et al. (2011). A novel GJA3 mutation associated with congenital nuclear pulverulent and posterior polar cataract in a Chinese family. Hum. Mutat. 32: 1367-1370.

Zeppieri M, Salvetat ML, Beltrami AP, Cesselli D, et al. (2013). Human adipose-derived stem cells for the treatment of chemically burned rat cornea: preliminary results. Curr. Eye Res. 38: 451-463.

Zhang F, Sugar A, Jacobsen G and Collins M (2011). Visual function and spectacle independence after cataract surgery: bilateral diffractive multifocal intraocular lenses versus monovision pseudophakia. J. Cataract. Refract. Surg. 37: 853-858. 